\title{
"THIS IS THE TIME. AND THIS IS THE RECORD OF THE TIME”
}

Under det tidiga 1700-talet kommer en ung kvinna "of distinguished, Birth, Beauty, Wit, and Spirit” till London (Haywood 257). Ett besök på stadens teater väcker hennes nyfikenhet inför de kvinnor vilkas enda syfte är att knyta bekantskap med så många män som möjligt, och inför de sätt på vilka de uppvaktas av männen. För att stilla sin nyfikenhet maskerar hon sig som en prostituerad och ger sig själv namnet Fantomina. Vid nästa teaterbesök är hennes uppvaktare mångfaldiga. Men berättelsen tar en ny början då en för kvinnan inte helt okänd man, med det mycket franska namnet Beauplaisir, träder in på scenen: Begäret snarare än nyfikenheten kommer nu att driva berättelsen framåt. Fantomina och Beauplaisir inleder en relation, eller snarare ett arrangemang. Snart nog tröttnar Beauplaisir på monotonin och försöker återta sin frihet för att söka nya erövringar. Med hjälp av en lång rad förklädnader och namnbyten kommer emellertid denna unga kvinna att (åter)erövra den intet ont anande Beauplaisir gång på gång. Hennes begär är inte svagare än Beauplaisirs, och det är i en mening kanske heller inte mindre flyktigt till sitt objekt: för varje ny roll som hon antar, kommer också Beauplaisirs begär och uppvaktningsformer att ta sig nya uttryck.

Denna kvinnas liv - låt oss kalla henne Fantomina, då hennes födelsenamn förblir oss obekant berättelsen igenom - utspelas i novellen Fantomina: or Love in a Maze, författad av Eliza Haywood under det tidiga 1700-talet. Valet av denna novell kan tyckas märkligt $\mathrm{i}$ ett temanummer som skall behandla övervakning $\mathrm{i}$ relation till samtida konst. Men valet har sina skäl. Dagens extensiva användning av kroppar i olika datoriserade övervaknings- och identifieringssystem genererar en rad historiska och teoretiska frågor rörande relationen mellan kroppar, teknologi, information och makt; inte minst reser den frågor om så kallade kroppsliga fri- och rättigheter. Och trots de historiska förändringar som har skett inom de övervakande makterna sedan tiden för denna novell, tycks den form av individualism som Fantomina spelar upp i denna berättelse - en individualism som jag snart får skäl att återkomma till - även sätta sin prägel på samtida juridiska begrepp om integritet, liksom på kroppsliga fri- och rättigheter i en vidare mening. Med den syn på kroppen som information och den sammanhängande föreställningen om världen som skrift som kommer till uttryck i förarbeten till några svenska lagar rörande användningen av DNA i identifierande syfte - dels i relation till misstänkta 
brottslingar, dels i relation till anhöriginvandring - tycks för att tala med Roland Barthes, dessa kroppar, om än på nya sätt, fångas i “skriftens fälla” (Barthes 5). Men varken världen eller kroppen är kanske skrift, även om texter - också dammig byråkratisk prosa - bär världar inom sig vilka kan läsas från olika perspektiv. ${ }^{1}$ Och i den mån som kroppar har förståtts som skrift av de övervakande makterna, kan kanske också litteraturteori likväl som litteratur bidra till att blottlägga innebörderna av denna förståelse.

Kroppen, skriver Judith Butler, är platsen för en gemensam sårbarhet, men en sårbarhet som alltid artikuleras på olika sätt (Butler 2004, 44). Och den kritiska fråga som infinner sig vid en läsning av riksdagsdebatter och förarbeten till samtida lagar är hur att förstå denna sårbarhet i relation till användningar av kroppen i samtida identifieringssystem? Frågan ter sig desto viktigare då olika former av identifieringar är centrala för varje övervakningssystem. Mitt syfte är inte att täcka alla kritiska aspekter rörande exempelvis nationella och transnationella genetiska databaser, inte heller att betona det specifikt svenska i dessa lagar eller göra en jämförelse mellan Sverige och andra länder. Mot bakgrund av frågan om vad periferi betyder i relation till globalisering - särskilt då det handlar om emigration och föreställningar om säkerhet och kontroll - skall jag istället försöka mejsla fram de olika föreställningar om kroppar, deras integritet och rättigheter som kommer till uttryck i detta material.

För att anknyta till den rad ur en låttext av Laurie Anderson som utgör artikelns rubrik, ${ }^{2}$ så handlar det både om att försöka behandla identifieringsproblematiken i dess historiska komplexitet, och att försöka lyfta fram de mönster som dessa insamlande och lagrande makter med viss kontinuitet över tid kan sägas spela upp. Inte minst handlar det om att försöka förstå dessa identifierade kroppar i relation till tid och rum, och den sammanhängande uppgiften att formulera en kritisk förståelse av den människosyn som kommer till uttryck i detta juridiska material - samt av de politiska, etiska och juridiska implikationerna av denna antropologi. Och trots den vanliga kritiken gentemot teorier som på ett eller annat sätt decentrerar subjektet - en kritik som hävdar att dessa teorier inte kan artikulera politik, rättigheter eller etik ${ }^{3}$ - så vill jag avslutningsvis undersöka om det är just genom att beakta det mellanrum som, enligt Hannah Arendt, inter est, och således genom att beakta de sätt på vilka min existens förutsätter de andra i mig, som det är möjligt att diskutera frågor om rättigheter, etik och politik på ett meningsfullt sätt. Detta också, och kanske framförallt, då det handlar om de konstitutionella kroppsliga

1 För en kritisk diskussion om metaforen "världen som text" se Schuback.

2 Raden "This is the time. And this is the record of the time." är hämtad från låten "From the Air". Laurie Anderson. Big Science, Warner Bros Records, 1982.

3 För en diskussion och kritik av denna kritik, se Butler 2001, 22-40. Som Butler skriver: "if it is precisely by virtue of its relations to others that it is opaque to itself, and if those relations to others are precisely the venue for its ethical responsibility, then it may well follow that it is precisely by virtue of the subject's opacity to itself that it sustains some of its most important ethical bounds.”(22) Även om min artikel har ett annat fokus, då den framförallt rör frågor om så kallade kroppsliga fri- och rättigheter, så är opakheten central för den alternativa syn på rättigheter och politik som jag kommer att behandla med hjälp av Hannah Arendts texter. 
fri- och rättigheterna, likväl som integritet. Arendt ställer oss inför den dubbla utmaningen att, i uppgörelsen med bland annat individualismen, inte upplösa subjektet på ett sådant sätt att vi förbiser de sätt på vilka kroppar fortfarande kränks: Och det är denna utmaning jag skall gripa mig an. Men låt mig först närma mig Fantomina utifrån några olika relationer mellan fiktion, makt och övervakning och därigenom lägga ut några spår för den fortsatta analysen.

\section{Fiktionernas makt}

Att fiktioner har en central roll i olika maktteorier är välbekant. Där Thomas Hobbes suveränitetsteori har sin grund i föreställningen om den andras makt - det vill säga i ett gränslöst begär efter den makt som man fruktar att den andre har är fiktionerna också avgörande för den disciplinära makt som Jeremy Bentham tematiserar, där fiktionerna tar sig olika uttryck inom och utanför Panoptikons murar (Hobbes 70 [47]); Bentham; se även Bozovic). Men också i kommentarer och förarbeten till den svenska strafflagen finner vi en sekellång diskussion som rör fiktionens motiv. När en svensk lagkommitté 1834 använder termen fiktion för att benämna en av strafflagens påföljder - nämligen påföljden borgerlig död är skälet att denna påföljd omvandlar ännu levande mänskliga varelser till döda. ${ }^{4}$ ("Utlåtande" 75) Påföljden, eller straffet, definierades under det tidiga 1900-talet som "förlust av medborgerligt förtroende". Dess historia kan återföras till bannlysningsinstitutet, och den har tidigare beskrivits i termer av bland annat vanfrejd, ärelöshet och borgerlig död (Inger). Men praktiken har också varit omdiskuterad under många sekel. Och vid 1734 års riksdag anmärkte en av ledamöterna apropå ärelöshet att man bör sluta utdöma straff som innebär att den frigivne kommer att vara såsom en "lefwandes död” ibland oss ("Anmärkningar" 224). Under det tidiga 1800-talet ville istället juristen Johan Gabriel Richert utvidga dödens retorik: de fängelserum i vilka fångar som dömts till total ärelöshet hålls förvarade bör benämnas gravar, eftersom dessa ärelösa är såsom döda för samhället (Richert 142). 5

4 Nämnas kan att Johan Gabriel Richert, som tidigare hade förespråkat påföljden, ingick i denna kommitté.

5 "Med fängelse på lifstid vill jag”, skriver Richert (142), "uttrycka begreppet af borgerlig död". Richert föreslår även att den borgerligt döda då minst tio år har förflutit skall kunna återskänkas borgarerätten och "under annat namn, intagas i staten och der börja ett nytt lif.” Också när tidigare epokers manifestationer av skamstraffen - så som exempelvis offentliga spöstraff, eller brännmärkningar och stympningar av de vanfrejdades kroppar - upphörde, skrevs upplysningar om vanfrejden in i prästbetygen. Detta innebar, som konstateras i en utredning från 1917, "att det enda legitimationspapper den frigivne i allmänhet äger, innehåller bevis om att han 'suttit inne' för ett jämförelsevis svårt brott”. "Utredning och förslag om borttagande ur lagstiftningen av straffpåföljden förlust av medborgerligt förtroende". Bihang till riksdagens protokoll vid lagtima riksdagen $i$ Stockholm air 1917. (Andra samlingen. Andra Avdelningen. Andra Bandet: 1, MOTIV) Stockholm: 130. Se även "Motiver". Förslag till Allmän Criminallag (1832. Andra upplagan, med de förändringar hwilka Lag-committen wid slutlig granskning af förslaget infört). Stockholm, 1839. Påföljden avskaffades så sent som 1937. 
Praktiken att med lagens hjälp frånta människor deras rätt och ära har en lång historia i Sverige. Den visar att skammen har varit ett verktyg för den statliga rättskipningen från medeltiden till modern tid, och att den suveräna makten över undantaget - makten att upphäva lagen för att tala med Carl Schmitt - i själva verket också är knuten till sociala uteslutningsprocesser (Österberg 180; Schmitt 87f.). När dessa rättslösa registrerades och uppgifter om dem arkiverades så tycks arkiven, som Wolfgang Ernst skriver med hänvisning till Arlette Farge, handla "om försvinnande; genom en anhopning av minne försöker de driva ut rädslan för förlusten.” (Ernst 23, jmf. 51) Och denna förlust är en förlust av liv. Det skapas en korpus av papper som behandlar om inte lik så levande döda. Det handlar om vanfrejdiga liv, som med Michel Foucaults ord "spelas upp” ['jouées'] i några få meningar. Verkliga liv, som inte representeras, utan vilkas öde - frihet, olycka och ofta död - avgjordes i dessa meningar. Och de existenser som riskerades och förlorades i dessa ord återkommer till oss endast genom den arkiverande maktdiskurs som fördrev dem från de levandes krets (Foucault 2000, 160). ${ }^{6}$

Men identitetshandlingarnas historia med början i det förmoderna Europa utgör, som Valentin Groebner påpekar, också i en vidare mening en förvandlingshistoria. Det är först genom föremål - sigill, märken, lejdebrev och pass - som man förvandlas till en viss person: till det som intygas i och utanpå handlingen, och i de registersystem till vilka handlingen är kopplad. Dessa föremål visar med andra ord att autenticiteten hos något, eller någon, skapas först genom kopior, eller genom de repliker som produceras (Groebner 2009, 180, jmf. 38f., 131, 193). Och administrativa institutioner gör sig inte gällande genom att de så effektivt som möjligt anpassar sig till den omgivande verkligheten. Istället uppvisar dessa system själva, som Groebner skriver, med nödvändighet "drag av fiktion (eller aspekter av administrativ abstraktion, om vi föredrar det)" (Groebner 2009, 179, jmf. 132f.). Med Ernsts ord översätter vi inte verkligheten "till en klassifikation, utan det är själva den klassificerande formen som ger oss besked om verklighetens arkivstruktur.” (Ernst 29)

Snarare än att utgöra det som finns kvar efter slutet, bildar arkivet således från första början "det främsta rastret för registrerad verklighet." Därför bör vi även förstå samtidens identifieringspraktiker i termer av förvandlingshistorier - även om fiktionernas materiella förutsättningar har förändrats - och låta den kritiska diskussionen om juridiska fiktioner vägleda oss i arbetet med att avfrosta eller

6 Formuleringen att dessa liv "spelades upp", är som Giorgio Agamben skriver tvetydig. Inte främst för att uttrycket kan ha en teatralisk mening, utan eftersom frågan om agenten - det vill säga frågan om vem som sätter dessa liv i spel - inte ges något svar i Foucaults text. Var det de vanfrejdade människorna som själva reservationslöst hängav sig? Eller var det snarare - vilket, som Agamben skriver, verkar troligare - de familjemedlemmar som vände sig till suveränen med sina anklagelser mot en släkting eller anhörig, de anonyma ämbetsmännen och polismännen som ansvarade för deras inspärrning, som satte dessa liv i spel. Med Agambens ord: "The infamous life does not seem to belong completely to either one or the other; it belongs neither to the juridical identity that will have to answer for it nor to the functionaries of power who will judge the infamous men in the end. The infamous life is only played; it is never possessed, never represented, never said - and that is why it is the possible but empty site of an ethics, of a form of life." (Agamben 2007, 68). 
denaturalisera samtida begrepp som exempelvis "illegala immigranter". För dessa "levande döda" - de gränsgestalter, som med lagens hjälp fördrevs från de levandes krets - ställer oss inte bara inför namngivandets problematik, utan kastar också ljus över de processer genom vilka människor, idag också på global nivå, fråntas sina rättigheter för att skapas så som illegala. Utan hem och identitetshandlingar riskerar dessa liv att utspelas i ett permanent undantagstillstånd, liksom de vart de än beger sig kommer att stå i en intim relation till mer eller mindre suveräna övervakande makter: såväl till traditionella övervakande makter, så som underrättelse- och säkerhetstjänster, som till den mångfald också av andra makter som idag avkräver oss identitetsbevis.

Och kanske finner vi ett av de mer signifikanta uttrycken för relationerna mellan övervakning, makt och fiktion om vi vänder oss just till underrättelse- och säkerhetstjänsterna. Betydelsen av att studera dessa mer eller mindre hemliga tjänster, och inte minst att studera den offentliga diskurs som omger dem och de uppgifter och metoder som åläggs dem av de offentliga makterna, blir desto större då flera tendenser inom dagens övervakning - så som användningen av sannolikhetskalkyler, kunskapsbearbetning och föregripande åtgärder - såväl inom kommersiell som statlig och överstatlig övervakning, består i ett ökat säkerhetstänkande (Amoore 25ff.; Haggerty \& Ericson 11ff.; Galloway \& Tucker 35). Därmed finns det goda skäl att dels ställa frågan om dessa tendenser utgör ett övertagande av de traditionella säkerhets- och underrättelsetjänsternas metoder och dels att undersöka hur dessa metoder gestaltas i byråkratisk prosa. Till underrättelsetjänsternas uppgifter hör, som det står att läsa i den svenska statens offentliga utredningar (SOU), inte bara att spara information från det förflutna, utan även att spåra risken för ett framtida brott. Därför kräver bedömandet av vilka uppgifter som skall föras in i register inte bara "kombinationsförmåga och förutseende", utan också "fantasi”. 7 Om "[r] omanskrivandet är en fortsättning på spionaget med andra medel”, som Friedrich Kittler påstår, så gäller med andra ord också att säkerhetstjänstverksamhet är en fortsättning på romanskrivandet med andra medel (Kittler 178). Så låt oss återvända till Fantomina.

\section{Love in a maze. Eller vad tidigmodern fiktion kan lära oss om identifiering och politik}

Fantomina: or Love in a Maze erinrar om de berättelser som var mycket populära under den tidigmoderna epoken, som också såg en lång rad identifierings och overvakningssystem ta form: Berättelser i vilka identitetsbedrägerier och personförväxlingar

7 För det första citatet se, "SÄPO. Säkerhetspolisens arbetsmetoder, personalkontroll och meddelarfrihet. Slutbetänkande av SÄPO-kommittén”. SOU 1990:51. Stockholm: Civildepartementet: 148. Om fantasi se, "Säkerhetspolisens arbetsmetoder. Rapport av särskild utredare”. SOU 1989:18. Stockholm: Civildepartementet: 50. Nämnas skall att fantasin inte är absolut, utan i långa stycken genrebestämd, vilket blir uppenbart om man ser till vilka kategorier av människor som underrättelse- och säkerhetstjänsterna har föreställt sig som särskilt hotfulla. 
iscensattes i mycket intima situationer (se Doniger; Groebner 2001, 22ff.; Zemon Davies 108; Shapiro 1, 16ff., 199ff.). Men det centrala temat i Fantomina utgörs inte av en man, hustru eller älskare som förförs av någon som utger sig för att vara deras partner: Fantomina använder istället sina masker för att så som en vara ständigt kunna erbjuda nyhetens behag. Innan novellens slut har huvudpersonen hunnit anta en rad av de identiteter som var tillgängliga för tidens kvinnor. Efter att ha spelat den prostituerades roll förvandlar sig Fantomina först till en tjänsteflicka, därefter till en sörjande änka, för att till sista anta rollen av en kvinna inom den extrema överklassen. Berättelsen tycks få ett tragiskt slut då kvinnan blir gravid, maskeraden avslöjas och hon förpassas till ett kloster. Och detta avslöjande är inte ett avslöjande i en bokstavlig mening: snarare straffas hon för att inte ha uppfyllt den ursprungliga och högt värderade roll som samhället tillskrivit henne på grundval av hennes klass och kön.

Haywoods författarskap under 1720-talet kännetecknas, som Paula R. Backscheider formulerar det, av en tendens till mjukporr, samtidigt som det är rikt på sociala kommentarer - två aspekter som är intimt relaterade. Haywoods utforskande av tidens sexuella ideologi, utgör samtidigt en utforskning av dess betydelse för identitetsskapande och för utövandet av makt och privilegier (Backscheider $\mathrm{xx}$, xxxiii). Och även om Fantomina förtjänar en närmre läsning så är det bland annat det faktum att den kan läsas som en kommentar till samhällets identitetshierarki, och av de friheter respektive begränsningar som olika positioner erbjuder, som förlänar den en plats här. Liksom någons, eller någots, originalitet skapas och garanteras först genom de kopior och repliker som produceras så är man i ett identifieringssystem heller aldrig bara sig själv, utan också någon annan - en representant för en kategori, eller en typ. ${ }^{8}$ Men denna fiktion får också en ytterligare betydelse om vi så att säga förflyttar oss till Fantominas position och läser denna i relation till en individualistisk antropologi.

Ett drygt sekel efter Fantominas entré, under 1850-talet, fastslår John Stuart Mill, i sin klassiska text Om fribeten att "[ö]ver sig själv, över sin egen kropp och själ är individen suverän” (Mill 18). Därmed ger han en koncis definition av individbegreppet så som det kom att utvecklas inom en liberal tradition - en tradition för vilken John Lockes begrepp om människan som en oberoende ägare av sig själv är central, inte bara för förståelsen av mänsklig individualitet: såväl politiskt handlande och frihet, som rättigheter förstås som en del av människans suveräna ägande av, och kunskap om, sig själv - sin kropp, likväl som sina tankar (Locke 350, passim). Föreställningen att man har rätt till sin kropp har enligt en lång filosofisk tradition tolkats både i relation till det privata, som en rätt till hemligheter, och till det offentliga, som en rätt till sina åsikter (Liedman 61f.; Johansen 2005, 54ff, 151ff.). Och den svenska regeringsformens skydd för de kroppsliga fri- och rättigheterna rör inte bara skyddet mot kroppsstraff, tortyr och olika slag av kroppsliga ingrepp - till denna kategori

8 Om relationen mellan att identifieras som en enskild individ och som representant för en kategori, se Caplan (51). 
räknas exempelvis också rörelsefrihet liksom skydd mot husrannsakan och intrång i post, brev och teleförbindelse samt mot hemlig avlyssning. Skyddet för kroppsliga fri- och rättigheter förstärker dessutom de så kallade opinionsfriheterna: de föreskrifter som skyddar den enskildes rörelsefrihet, skyddar indirekt också dennes möjlighet att utöva demonstrationsfrihet, yttrandefrihet etcetera. ${ }^{9}$

Frågan är emellertid om den filosofiska tradition som här antyds - en individualistisk, företrädesvis liberal, tradition - förmår erbjuda en kritisk förståelse av de kroppar som analyseras och knyts till datorer inom olika identifieringssystem. Snarare tycks det, som jag får skäl att återkomma till, vara en juridisk föreställning om individen som en enhet med fasta gränser, och som en oberoende och transparent ägare av sig själv, som gör det möjligt att hävda att dessa användningar av kroppen inte är integritetskränkande. Då Hannah Arendt i en ofta förbisedd passage i Människans villkor istället, med en hänvisning till antiken, skriver att egendomens sfär var privat i en icke privativ mening, kullkastar hon emellertid denna föreställning. Karaktären av att vara förborgad från offentligheten "svarade mot det enkla faktum att människan inte vet varifrån hon kommer när hon föds eller varthän hon går när hon dör.” (Arendt 1988, 88) Betydelsen av egendom (Eigentum) - ett ord vars etymologi är knutet till självet, till betydelsen av att vara sin egen (eigen), att vara unik (eigentümlich) - blir i Arendts filosofi själva omöjligheten att apropriera livets början och dess slut. Det som är mig mest eget är samtidigt det mest främmande. Därmed bryter Arendt helt med de individualistiska traditionernas syn på egendom och på människan som en varelse i besittning av sig själv.

Själva min tillblivelse förutsätter både en värld och andra som villkorar - om än inte ensidigt bestämmer - vem jag kommer att bli. Men de aspekter av vem någon är som framträder för andra då vi handlar och talar - vilket för Arendt är de politiska aktiviteterna - förblir alltid delvis fördolda för mig själv (Arendt 1988, 212ff., jmf. Cavarero 2000, 36). Därför kan en unik levnadshistoria, enligt Arendt, endast återberättas postumt. Med Adriana Cavareros formulering kan livet inte "levas som en berättelse, eftersom berättelsen alltid kommer efteråt [...]; [berättelsen] är oförutsebar och okontrollerbar, just som livet." (Cavarero 2000, 3) Denna unicitet utgör med andra ord något helt annat än ett spel med masker och löser varken upp jaget i en suverän diskurs, eller tillskriver det en lika suverän individualistisk identitet. Och kanske är det med hjälp av dessa diametralt skilda sätt att se på mänsklig egendomlighet, som vi kan förstå Fantominas öde, för faktum är att redan Fantomina tycks spela upp några av de politiska paradoxer som följer av en individualistisk människosyn: Det är då Fantomina försöker göra sig till en suverän författare till sitt liv, och leva det som skrift, som hon blir som mest underordnad: ett subjekt i ordets bokstavliga mening. Genom att försöka iscensätta sitt liv som en berättelse blir hennes maskerade beteende, skulle vi kunna säga, teatraliskt, utan att utgöra ett framträdande: hennes unicitet kommer, som jag får skäl att återkomma

9 För en genomgång med hänvisning till förarbeten av relevans se, "Skyddet för den personliga integriteten. Kartläggning och analys. Delbetänkande av integritetsskyddskommittén.” SOU 2007:22. del I, sid. 50. 
till avslutningsvis, aldrig till uttryck i tal och handlande med andra. Och trots att det är begäret som utgör berättelsens drivkraft så tycks, för att tala med Roland Barthes, det som förloras i transkriptionen vara just en kropp:

"at least this exterior (contingent) body which, in a dialogue, flings toward another body, just as fragile (or frantic) as itself, messages that are intellectually empty, the only function of which is in a way to hook the Other (even in the prostitutional sense of the term) and to keep it in its state of partnership." (Barthes 5)

Kroppen är förvisso, som Barthes skriver, fortfarande närvarande ("no language without a body") men i transkriptionen ersätts appellen, kontakternas spel, med intresset att representera en argumentation. Vad som följer är en underordning, en hierarki av olika roller och scenpositioner: då meddelandet blir socialt, återvinner det “en ordnande struktur; 'idéer”" (Barthes 5-6). Genom sitt beteende blottlägger Fantomina en rad av de kategorier som är möjliga för henne på samhället scen: men på denna sociala scen förblir inte bara Fantomina utan också Beauplaisir utbytbara vad. Och kanske är det denna läsning som Haywood själv föreslår då hon låter huvudrollsinnehaverskan i sin sista roll bära namnet Incognita, innan hon förpassas till klosterlivets lika individualiserade som anonyma tillvaro. ${ }^{10}$

Samtidigt som Fantominas liv, så som vi lär känna det, formas av begäret efter en man tycks hon med andra ord i sina handlingar spela upp en individualistisk antropologi och i vidare mening en individualistisk politik (vilket inte är detsamma som Haywoods politiska hemhörighet). Och frågan är om inte de juridiska implikationerna av denna individualism kommer till uttryck också i samtida lagar. Så låt mig fortsätta där, och med Fantominas hjälp analysera de identifieringssystem i vilka människor blir till subjekt i ordets dubbla mening.

\section{Skriftens fälla}

Materialet består av förarbeten och riksdagsdiskussioner rörande två lagar som trädde ikraft 2006. En lag rör användningen av DNA i vissa fall av anhöriginvandring, som bevis på familjeband då dokument saknas eller ses som otillförlitliga. Den andra möjliggör en utvidgad användning av DNA i brottsundersökningar. Kortfattat innebär denna utvidgning att det nu är möjligt att föra in uppgifter i DNA-registret avseende personer som dömts för brott som inte anses som allvarliga: det handlar bland annat om ungdomar som gjort sig skyldiga till snatteri, stöld och tillgrepp av fortskaffningsmedel ("Utvidgad användning av DNA-tekniken" [Prop. 2005/06:29] 19f.). 2006 års lag gör det också möjligt att, i ett nyinrättat

10 Vem någon är i sin unicitet är, skriver Hannah Arendt, inte detsamma som vad man är med vissa talanger, brister och gåvor, det vill säga egenskaper man kan dela med andra (Arendt 1988, 212ff.) Ett unikt vem är inte orelaterat till de positioner som är möjliga i tid och rum - tvärtom skapas min unicitet kontinuerligt genom de relationer i vilka jag framträder för andra i världen. 
utredningsregister, registrera uppgifter från DNA-analyser även om syftet enbart är att tillgodose ett eventuellt framtida behov, det vill säga att registrera misstänkta brottslingar. ${ }^{11}$ Lagarna är svenska men kontexten är, åtminstone, europeisk liksom de ger uttryck för ett antal generella tendenser - och då inte bara för den snabba expansionen av DNA-databaser, utan också för den vändning mot föregripande övervakning som behandlades inledningsvis.

För att det skall vara förenlig med regeringsformen att ta ett DNA-prov krävs att åtgärden står i proportion till vad som vinns med den. Vid denna bedömning måste man, som jag snart får skäl att återkomma till, ta hänsyn till vilket intrång provtagningen utgör för den enskilde. Men man måste också, som det konstateras i en av propositionerna, ta ställning "till hur känsligt innehållet i själva provet eller registeruppgiften är”. Och, låt mig börja här - med frågan om provets eller registeruppgiftens innehåll - ett innehåll som förstås i termer av information. Olägenheten att myndigheterna genom provtagningen får tillgång till biologiskt material, ur vilket det kan tas fram information om den enskilde, är enligt regeringen i praktiken begränsad. I och för sig framkommer det vid DNA-analysen "information om sådant som får anses integritetskänsligt, t.ex. uppgifter om könskromosomer. Det analyserade resultatet omvandlas emellertid till en sifferkombination (profil) som endast innehåller uppgifter om den undersöktes identitet och det är endast denna profil som läggs in i registret. Den uppgift som förs in i registret kan alltså inte anses vara av särskilt känsligt slag” ("Utvidgad användning av DNA-tekniken”, 22).

Med denna formulering tycks vi stå inför en form av informationsessentialism, i vilken informationsmönstret ges företräde framför materia. Samtidigt är blicken fortfarande privilegierad. Som N. Katherine Hayles skriver i ett annat sammanhang, är drömmen att med hjälp av informationsteknologi, "peer directly into the elements of the world before the world cloaks itself with the appearance of complexity." (Hayles 1999, 233) "Vid en kriminalteknisk DNA-analys undersöks", som det står att läsa i en proposition, "inte mer än cirka en miljondel av arvsmassan. Undersökningen är inriktad på de områden som varierar mycket mellan olika individer." Dessa områden "har så vitt man känner till ingenting att göra med en persons synliga egenskaper, såsom utseendet, eller karaktärsegenskaper.” (“Utvidgad

11 Förutsättningen är att personen är skäligen misstänkt för brott på vilket fängelse kan följa, men till skillnad från vad som gäller beträffande DNA-registret krävs inte att DNA-provet har betydelse för utredningen av brottet ifråga. Provet tas och uppgifter registreras istället med syftet att informationen kan vara bra att ha i framtida brottsutredningar (Skyddet för den personliga integriteten [SOU 2007:22]. del I, 213, se även 178; samt "Utvidgad användning av DNA-tekniken” [Prop. 2005/06:29], 1). I polisdatalagen (1998:622) fanns sedan tidigare bl.a. bestämmelser som ger polisen möjligheter att föra två olika register som innehåller uppgifter från DNAanalys. Dels ett DNA-register som innehåller uppgifter om DNA-analyser av sådana prov som har tagits under brottsutredningar från personer som har dömts för vissa grova brott. Dels ett spårregister som innehåller uppgifter om DNA-analyser av spår som har gjorts under brottsutredningar och som inte kan hänföras till en känd person ("Utvidgad användning av DNA-tekniken" 10). De utvidgade möjligheterna att registrera uppgifter från DNA-analyser innebär, som Integritetsskyddskommittén skriver i en utredning från 2007, att man avviker från Europarådets rekommendation - något Sverige sällan gör (Skyddet för den personliga integriteten, del 1, 213f., 178, 453). Den rekommendation som åsyftas är Europarådets rekommendation No. R (92) 1. 
användning av DNA-tekniken” 11) Och här finner vi kanske inte bara ett skäl till varför det inte är möjligt att artikulera sårbarheten hos dessa kroppar med hjälp av ett traditionellt integritetsbegrepp. Kanske bör vi också, liksom i Fantominas fall, fråga oss om inte problemet med denna kroppsuppfattning är att den realiserar själva individualismen; som abstrakta enheter blir vi inte bara radikalt åtskilda från varandra, utan också en och den samma.

Denna form av informationsessentialism innebär att allt som inte ryms $\mathrm{i}$ informationsbegreppet kommer att bortfiltreras och reduceras till biprodukter. Då kroppsinformationen frikopplas från mediets materiella och teknologiska begränsningar, likväl som från andra kontexter, tillskrivs informationen universell giltighet. ${ }^{12}$ Men denna abstrakta universalism visar sig som partikularism då kropparna kodas efter hierarkiska idéer med ett långt historiskt förflutet. Att så är fallet blir än tydligare i de förarbeten som rör användningen av DNA i vissa fall av anhöriginvandring. Genom möjligheten till DNA-analys "ges sökanden förutsättningar att visa att biologiskt släktskap föreligger i ärenden där den övriga utredningen om släktskapet inte är tillräcklig för att ansökan om uppehållstillstånd skall kunna beviljas." ("Genomförande av EG-direktivet om rätt till familjeåterförening” [Prop. 2005/06:72] 70-71) DNA-analysen, upprepas det vid ett flertal tillfällen, sker av hänsyn till skyddsaspekten och barnets bästa, den är ett erbjudande och samtidigt "ett hinder mot att barn sammanförs med personer som inte är deras föräldrar."13

Blicken lämnar en värld full av brus, och dokument - om sådana finns, vilka misstänks vara fulla av fel: otillförlitliga stämplar; signaturer och foton - för att slå sig till vila i en förenklad skrift. En skrift som antas rymma den sanna informationen och att generera säkerhet och kontroll. Och då regeringen, trots invändningar från Barnombudsmannen (BO) och flera andra remissinstanser, väljer att söka de verkliga relationerna i den genetiska informationen framträder en process i vilken flyktsituationen - så som krig i vilka våldtäkter är mycket vanliga - likväl som faktiska beroendeförhållanden och relationer bortfiltreras. ${ }^{14}$ Kroppen är, för att återvända till skriftens fälla, fortfarande närvarande men i transkriptionen ersätts appellen, kontakternas spel, med intresset att representera en argumentation. Vad

12 En, för att tala med N. Katherine Hayles, posthumanistisk förståelse av information, om än en förståelse med långa rötter bakåt i tiden. För en diskussion om informationsessensialism i relation till kroppsuppfattningar se Hayles (2002, 319f.), Thacker (76-85), samt, rörande informationens materialitet, Galloway \& Thacker (41).

13 "'Genomförande av EG-direktivet om rätt till familjeåterförening", 70-71. I propositionen behandlas även bland annat barnets rätt till "grundläggande rättigheter som omvårdnad, trygghet och god fostran" vilka finns inskrivna i föräldrabalken. Denna rätt till trygghet "omfattar bl.a. rätten att få leva i ett stabilt förhållande och att ha någon att lita på”, en rätt som i propositionen emellertid entydigt tolkas utifrån den biologiska familjens företräde: "I detta ligger å ena sidan ett intresse av att låta barnet få växa upp i sin invanda miljö, å andra sidan intresset av att värna om barnets bästa genom att förhindra att det utsätts för brottsligt utnyttjande eller överges. Genom införandet av en möjlighet till DNA- analys i ärenden om uppehållstillstånd på grund av anknytning, kan barnet lättare skyddas mot sådant utnyttjande." (69f.)

14 Som Barnombudsmannen konstaterade i sitt remissvar är det troligen ett vanligt fenomen att barn från krigshärjade länder kan vara resultatet av en våldtäkt, och att det för både kvinnan och barnet kan utgöra en stor risk om barnet visar sig ha en fiende till far (Barnombudsmannen. Remissvar). Men skälen till att mannen i en familj inte är den biologiska fadern kan självfallet vara många. 
som följer är en underordning, en social hierarki av olika roller och scenpositioner (Barthes 5f.). Där världens stökiga mångfald - mångfalden etablerade beroenden och relationer - i en första rörelse lämnar plats åt en förenklad abstraktion, ersätts denna abstraktion i en andra rörelse av ett familjärt begrepp om kroppen. Kravet på en genetisk samhörighet formuleras utifrån den heterosexuella familjens ideal: ett ideal vars exklusivitet knappast kan få en skarpare formulering. Det avkrävs som det exempel vilket medger eller förhindrar tillträde. ${ }^{15}$ Och detta exempel finns inskrivet i den genetiska informationen: Information lika abstrakt universell som socialt partikulär. Skriftens fälla är en dubbel fälla.

\section{Integritetens innehåll}

Men då integritetsfrågan diskuteras så tycks vi inte bara stå inför en dubblering av kroppen. Då regeringen argumenterar för att denna information inte är känslig eller integritetskränkande tycks det också ske en förskjutning av denna dubblering. Och kanske kan Immanuel Kant ${ }^{16}$ - och den avgrund som Kant öppnar upp i förnuftet, med sin strikta distinktion mellan teoretiskt och praktiskt - vara till hjälp för att mejsla fram den etikförståelse som kommer till uttryck i denna diskussion. ${ }^{17}$ Från ett teoretiskt perspektiv är människan en omständigheternas fånge och, precis som djuret, determinerad av naturlagarna. Som en del i det praktiska förnuftet är människan fri, ansvarig för och underkastad sina etiska val. Av betydelse här, är att denna etik har sin grund i en föreställning om transparens: som handlande har man kunskap om sig själv, medan man från ett teoretiskt perspektiv är ett objekt, ett opakt "Ting i sig”. Och, om vi återvänder till resonemanget rörande integritet, där regeringen hävdar att den uppgift som läggs in i registret inte är integritetskränkande, då resultatet av DNA-analysen omvandlas till en sifferkombination eller profil: vad denna proposition tycks säga är att det är just eftersom jag inte kan ha en etisk relation till min DNA-profil (vilken hör till naturvetenskaperna) som DNA-analysen och lagringen inte är integritetskränkande. Själva min naturliga opakhet, och ickekunskap om mig själv från ett teoretiskt perspektiv garanterar att min integritet inte kränks då resultatet av DNA-analysen registreras. Integritetsfrå-

15 Kravet på att bevisa genetiskt föräldraskap är också ett krav som inte åläggs svenska föräldrar - liksom det inom nationens gränser finns en rad utmaningar mot en biologisk familjeidentitet - varför den asylsökande den familj som kan uppvisa en biologisk samhörighet, samtidigt kan sägas avskiljas från nationen i just det ögonblick som den visar upp sin tillhörighet till den. För en diskussion om exemplets relation till undantag och suveränitet se Agamben (1998), 22).

16 Möjligen kan en metodologisk kommentar vara på sin plats rörande filosofiska texter och arkivmaterial. Jag är nu inte fullt så idealisk som att hävda att filosofernas tankar sipprar ned i samhället och sätter svärta i arkiven. Inte heller menar jag att dessa texter i någon vulgär-marxistisk mening utgör enkla reflektioner av sitt samhälle. Däremot menar jag att vi i somliga av dessa texter kan finna komplexa bearbetningar av tidens frågor och problem, och att de därmed kan hjälpa oss att upptäcka vilka specifika problem som är förknippade också med de mest "banala fakta". Om begreppet banala fakta, se Foucault (1990, 58f., 83).

17 Om vi läser dessa utredningar i relation till cybernetiken så är varken föreställningen om förnuftet som ett fluidum utan kropp, eller föreställningen om ett oberoende liberalt subjekt att förvåna (Se Hayles 1999, xi-xii, 287). För en diskussion om Kant i relation till DNA, om än från ett annat perspektiv, se Ruin. 
gan blir med andra ord löst på förhand genom en a priori distinktion mellan det teoretiska och det praktiska (en distinktion som återspeglas i distinktionen mellan naturvetenskaper och humanvetenskaper) och genom en förståelse av etik i termer av oberoende och självkunskap.

Detta är inte den enda förskjutning som sker när det kommer till frågan om integritet i propositionerna. Föreställningen om kroppen som underliggande skrift eller information, genererad av databearbetning, som har varit central i argumentationen följs inte av en rekonstruktion av den anatomisk-fysiska kroppens gränser, snarare det motsatta.

\section{Integritetens form}

Det finns ingen enskild erkänd eller allmänt etablerad definition av integritet, varken i en filosofisk mening eller i svensk lag (Skyddet för den personliga integriteten 53). I Svenska Akademiens ordbok beskrivs termen bland annat som att vara i oskadat eller ofördärvat skick, och tillståndet att inte ha varit utsatt för någon åverkan eller något intrång. Ordet kommer från latinets integritas, som är en avledning från integer vilket bland annat också har betydelserna hel och hederlig. Vidare betecknar termen inom folkrättens område statens territoriella gränser; dess okränkbarhet och dess bevarande i orubbat tillstånd. Termen kan också enligt SAOB beteckna självständighet, oberoende och frihet från inblandning.

Termen kan med andra ord sägas förutsätta en självklar gräns för kroppen, och integritetskränkningar blir därmed en fråga om kroppens insida, det vill säga om de fall då gränsen överskrids. Att distinktionen inte är så tydlig står redan klart då det gäller den anatomisk-fysiska kroppens öppningar vilka utgör en gråzon - eller snarare en gråskala där de olika öppningarna (öron, näsa, mun, anus, vagina) är inskrivna i en moralisk hierarki (Se van der Ploeg 2003, 67f.). Än mer problematisk blir den i relation till de röntgenstrålar som idag inte bara genomlyser bagaget eller patienten utan också flygresenärens kropp, och inte minst i relation till DNA. För regeringens resonemang om de utvidgade möjligheterna att ta DNA-prov och registrera dessa också då det gäller misstänkta personer är det emellertid den anatomisk-fysiska kroppens gränser som ligger till grund: I diskussionen om integritet inträder denna kropp på scenen, inte som en kontingent ömtålig kropp, utan som en fast enhet med givna gränser. För att provtagningen skall vara förenlig med regeringsformen krävs, som tidigare nämnts, att åtgärden står i proportion till vad som vinns med den. Vid denna bedömning måste man inte bara ta ställning till hur känsligt innehållet i själva provet eller registeruppgiften är, utan också "till vilket intrång provtagningen och registreringen utgör för den enskilde”. Och denna aspekt av integritetsfrågan diskuteras framförallt i relation till själva tagandet av DNA-prover, något som för den enskilde framställs som "förhållandevis harmlöst" (“Utvidgad användning” 20). ${ }^{18}$ Eftersom provtagningen begränsas till salivprov kan 
integritetsintrånget, skriver regeringen, "inte anses vara särskilt stort och motiverar inte någon skillnad i förhållande till vad den misstänkte får tåla när det gäller tagande av fingeravtryck. Det gäller även om det någon gång kan vara nödvändigt att ta provet mot den enskildes vilja." (“Utvidgad användning” 22) Eftersom olägenheterna för den enskilde framstår som begränsade gör regeringen bedömningen att de utvidgade möjligheterna till DNA-analys är förenliga med regeringsformen och Europakonventionen ("Utvidgad användning” 23, jmf. 24, 29). ${ }^{19}$

Ett flertal av argumenten går även igen i den proposition som behandlar DNAprov i relation till anhöriginvandring - men de har här också kompletterats med ett krav på frivillighet ("Genomförande av EG-direktivet” 74). Också på denna punkt är Barnombudsmannen $(B O)$ en av de remissinstanser som reser invändningar: även om analysen i teorin är frivillig anser $B O$ att förslaget innebär att den som inte accepterar "erbjudandet om DNA-analys har avsevärt sämre möjligheter att få ett uppehållstillstånd.” (Barnombudsmannen) I propositionen formuleras emellertid DNA-analysen i termer av en möjlighet och som "ett slags rättshjälp" för de sökande och anhörigpersoner för vilka det annars vore omöjligt att bevisa "de påstådda släktbanden” (“Genomförande av EG-direktivet” 74f.). Regeringens förslag kom att tillstyrkas av socialförsäkringsutskottet, som i sitt betänkande också betonade frivilligheten. ${ }^{20}$ Resonemanget förs inom ramen för ett klassiskt liberalt frihetsbegrepp och i termer av en fri vilja, ${ }^{21}$ men det är inte endast det faktum att argumentet appliceras på kroppar i rörelse som ger det ett hobbesiskt intryck. ${ }^{22}$ För kanske framkommer betydelsen av frivilligheten tydligast i följande mening ur propositionen: "Kravet på samtycke innebär också att förslaget inte kan anses stå i strid med det grundlagsstadgade skydd som enskilda åtnjuter gentemot det allmänna vad avser påtvingade kroppsliga ingrepp (2 kap. 6 § regeringsformen).” (“Genomförande av EG-direktivet”! 74) Med denna mening tycks regeringen instämma med Thomas Hobbes övertygelse att skräck och frihet är förenliga (Hobbes 146 [108]). Åtminstone för dem som (ännu) inte är en del av den statliga kroppen, och medförfattare till suveränitetens skrift.

19 "Från integritetsskyddssynpunkt är det dock lämpligt att uppgifter om misstänkta personer inte blandas med uppgifter om dömda personer. De DNA-profiler som avser icke-dömda, men skäligen misstänkta personer bör därför föras in i ett särskilt register, benämnt utredningsregistret.” (“Utvidgad användning” 30).

20 Som det formuleras i betänkandet: "Om det föreligger ett biologiskt släktskap mellan en förälder och ett barn är det emellertid svårt att tro att föräldern skulle avböja erbjudandet om att få släktskapet bekräftat.” (Socialförsäkringsutskottets betänkande) I riksdagsdebatten betonade ett flertal av debattörerna frivilligheten; möjligheten till DNA-analys är ett erbjudande. Några ifrågasatte emellertid frivilligheten, om än på olika grunder: Somliga ställde sig, liksom $B O$ kritiska till formuleringen genom att ifrågasätta huruvida erbjudande kan ses som frivilligt om en vägran till DNA-analys i praktiken visar sig påverka ansökan negativt. Andra däremot ville explicit göra frivilligheten till ett krav; en vägran att genomföra DNA-analys när övrig utredning är otillräcklig skall påverka bedömningen av uppehållstillstånd negativt och detta skall framgå av lagtexten (Riksdagens protokoll 2005/06:97, §7).

21 Något som för Hobbes är lika absurt som att tala om "a round Quadrangle; or accidents of Bread in Cheese; or Immateriall Substances; or of A free Subject;” Hobbes 34 [19]).

22 "A FREE-MAN, is he, that in those things, which by his strength and wit he is able to do, is not hindred to doe what he has a will to. But when the words Free, and Liberty, are applied to any things but Bodies, they are abused” (Hobbes 146 [108]). 
De immigrerande kropparna är inskrivna i en gammal berättelse rörande gränskontroll, och suveränitet: En berättelse om den statliga kroppen - the "One Person", med Hobbes ord - och dess integritet. ${ }^{23}$ Men även om suveränitetshandlingar har en historisk realitet och konkreta likväl som våldsamma effekter, så har suveränen inget huvud - ingen vilja som transcenderar ett immanent kraftfält, eller styrkerelationerna i en given situation. Suveränitet är en fiktion, inte bara i den meningen att vi inte kan förstå det suveräna beslutet som en vilja vilken överskrider alla andra viljor, utan också i den meningen att den aldrig har varit en insulär angelägenhet: snarare motsatsen. Den suveräna viljan och föreställningar om gränskontroll är knuten till globala styrkemätningar och den står i en nära relation till globala undantagstillstånd, likväl som till sociala normaliseringsprocesser, exempelvis neonostalgiska idéer om familjen (se Johansen 2007). Suveränitetens roll i moderna liberala demokratier skall emellertid inte underskattas - och denna tycks finna sin pendang i föreställningen om en suverän person.

Regeringen följer, som vi sett, två traditionella spår då de resonerar kring integritetsfrågan: Dels fokuserar den på själva handlingen att ta ett DNA-prov; och dels på skyddsvärdet av den personliga information som genereras. Och medan själva provtagningen inte ses som särskilt integritetskränkande - antingen eftersom teknologin gör att ett salivprov (prov från munhålan) är tillräckligt, vilket innebär att den anatomisk-fysiska kroppens gränser inte överskrids, eller eftersom kravet på frivillighet neutraliserar förbudet mot påtvingade kroppsliga ingrepp - ses heller inte innehållet som kränkande, eftersom det omformuleras och neutraliseras i en sifferkombination som faller utanför det praktiska förnuftets domän, och således utanför en etik grundad i transparents. För mig innebär detta att vi bör försöka tänka om kroppslig sårbarhet likväl som integritet utanför de ovan nämnda begreppen, definitionerna och doktrinerna. Men låt mig först återvända till föreställningen om kroppen som skrift, och försöka väva samman några av de trådar som hittills har lagts ut.

Som Michel Foucault skriver, har "den plågade, sönderhuggna, stympade kroppen, symboliskt brännmärkt $i$ ansiktet eller på axeln, död eller levande utställd till allmänt beskådande" allt mer undanskaffats (Foucault 1987, 14f.). Men det är snarare straffens ohyggliga skådespel än de plågade kropparna som allt mer har försvunnit, och i retoriken kring dagens så kallade högteknologiska eller kliniska krig, döljs en massiv ökning av andelen civila offer (Masters). Med den, i vid mening, kommunikationsteknologiska utveckling och med de utmaningar mot de tidigare centrala organisatoriska enheterna som skett sedan tiden för Foucaults texter har också tidigare maktformer genomkorsats av kontrollernas nätverk med deras vitt förgrenade rotsystem och ständigt föränderliga länkar (se Deleuze). Då databaser fylls med biometrisk och genetisk identifierande information och knyts till nätverk, ökas både lagrings/minneskapaciteten och kommunikationshastig-

23 "And he that carryeth this Person, is called SOVERAIGNE, and said to have Soveraigne Power; and every one besides, his SUBJECT.” (Hobbes 121 [88]). 
heten. Informationen blir tillgänglig vid olika tider, från olika platser. Och då identifieringspraktikerna är indragna en rad processer som genererar temporala likväl som spatiala förskjutningar, kommer också den identifierade kroppen och det sätt på vilket den bär vittne, att ändra skepnad (se Hayles 1999, 208-210). De genetiska och inte minst de biometriska tecknen, ofta osynliga för det mänskliga ögat, kan avkodas teknologiskt varthelst dessa kroppar beger sig. ${ }^{24}$ Med denna kodade kropp (en kod vars tillkomstsituation kan vara mer eller mindre känd för den som berörs, och vars uttolkning av säkerhetsskäl kan vara fördold för den som berörs) blir personers kroppar till mer eller mindre osinnliga vittnen mot dem själva. Då dess levnadshistoria knyts till en virtuell tid, där händelser i framtiden redan är i det förflutna i den mån som koder föregår den, kan denna kropp då den försöker korsa en nationell eller annan gräns redan på förhand vara välkommen eller exkluderad. ${ }^{25}$

Den kropp som idag identifieras abstraheras ut ur sin materiella omgivning, fragmenteras och kodas på skilda sätt i olika kontexter - och därmed antar den nya hybridiska former. ${ }^{26}$ Och denna kropp-maskin-information hybrid tycks ställa oss inför två utmaningar: Dels att inte bortse ifrån de sätt på vilka kroppar också tidigare i historien har ingått i hybridiska sammanhang - liksom tidigare maktformer inte helt har förverkat sin $\mathrm{kraft}^{27}$ - varför utmaningen att tänka kritiskt kring exempelvis lag och integritet blir en både historisk och teoretisk uppgift. Dels att inte låta den kritiska reflektionen över individualismen mynna ut i slutsatsen att vi skall ge upp krav på individuella rättigheter, eller grupprättigheter, så som i fall då vi argumenterar för skydd mot diskriminering. I ett antal kontexter måste vi, som Butler skriver, kunna presentera oss som avgränsade varelser, igenkännbara för lagen, eller som en gemenskap vilken delar några karaktäristika (Butler 2004, 24.). Detta gäller inte minst ifråga om identifieringssystem, där den enskilda kropp som fångas i skriftens fälla, ofta definieras genom dess tillhörighet till en diskriminerad grupp. Kroppen är med andra ord, liksom forna tiders brännmärkta eller stympade kropp, fortfarande det lösenord som öppnar och stänger dörrar, men denna kropp behandlas allt mer som en kroppslös storhet bortom tid och rum. Och här finns det skäl att återvända till Roland Barthes skriftbegrepp - inte för att kroppar är skrift i denna mening, utan av det skälet att de förstås, och används, som sådan

24 Med Irma van der Ploegs terminologi är dessa kroppar präglade: både unika och stigmatiserade (van der Ploeg 1999, 301).

25 Om koder och dess funktion som mer eller mindre osynliga lagar i cyberrymden, se Bogard (175); Solove. (3, 223); Lyon 13f., 23). Om de mångomvittnade svårigheterna att få felaktiga identifieringar - exempelvis då det handlar om personer som har fått sina namn uppförda på listor vilka förhindrar dem att flyga, eller har fått sina banktillgångar frysta - omprövade, och om identifiering som en del i vändningen mot föregripande åtgärder, se Amoore (23f.).

26 Som Haggerty \& Ericson formulerar det med en hänvisning till Donna Haraway blir den övervakade kroppen "allt mer en cyborg; ett kött-teknologi-informationsamalgam." (Haggerty \& Ericson 611, jmf. 606).

27 I fallet med anhöriginvandring sammanfaller snarast den av kontrollerna kodade kroppen, med några av disciplinens nostalgiskt normaliserande institutioner - familjen, men också arbetet och försörjningsförmågan - och med den suveräna makten över undantaget. 
av de övervakande makterna: de kontingenta och inte minst ömtåliga kropparna, indragna i vävar av relationer, ersätts av intresset att representera en argumentation och skrivs in i en ordningshierarki av olika roller.

Varje genetisk eller biometrisk identifiering utgör förvisso inte en kränkning, men den fråga som infinner sig vid arbetet med detta material är hur denna kropparnas ömtålighet eller sårbarhet, och därmed integritet (om det är en term vi fortfarande skall använda), kan förstås i relation till användningen av kroppen i samtida identifieringssystem. Hur kan vi artikulera denna sårbarhet istället för att endast diskutera den information som lagras, det vill säga utan att reproducera föreställningen om information och medvetande som ett fluidum utan kropp. Frågan är med andra ord hur vi kan artikulera kroppsliga fri- och rättigheter, utan att än en gång lämna kropparna därhän. Resonemangen kring integritet i de propositioner som diskuteras här indikerar att det inte är möjligt att artikulera dessa kroppars sårbarhet inom ett individualistiskt juridiskt ramverk. Snarare tycks det vara själva föreställningen om en individuell enhet med fasta gränser som, i kombination med en etisk förståelse av denna individ som genomskinlig för sig själv, gör det möjligt att hävda att sådana användningar av kroppar aldrig är kränkande - integriteten förblir intakt.

Tvärtemot vad individualismen (liksom vissa cybernetiska grenar) vill få oss att tro, är det kanske därför först med en reflektion över hur våra kroppar är våra egna i relation till tid och rum - som vi kan artikulera inte bara de identifierades kropparnas sårbarhet, utan också de former av politisk autonomi och frihet som står på spel. Om vi inte vill överta de övervakande makternas språk (och endast tala i termer av informationsflöden, högteknologisk övervakning och klinisk krigsföring) måste därför dekonstruktionen av begrepp som kroppslig integritet ske varsamt (jmf. Van der Ploeg 2003, 69), liksom vi även fortsättningsvis måste kunna "hävda att våra kroppar i en mening är våra egna," (Butler 2004, 25) och att vi därigenom är berättigade att göra anspråk på våra kroppars autonomi. Och kanske kan vi i formuleringen av dessa krav ta en utgångspunkt i några rader ur Hannah Arendts diskussion om egendom - och dess implikationer för en förståelse av integritet och autonomi. För dessa rader är inte bara av betydelse för en kritisk förståelse av Fantominas handlingar, utan öppnar också för en förståelse av politik och rättigheter som radikalt skiljer sig från en individualistisk tradition.

\section{Egendomlighet, eller: Om tillblivelse}

Egendomen, skriver Arendt i Människans villkor, har "uppenbarligen vissa egenskaper som trots sin privata natur ändå är av yttersta vikt för det politiska":

"Av politisk betydelse är [...] inte det inre av detta område, vars hemlighet inte angår offentligheten, utan dess yttre form, d.v.s. det som måste uppföras utifrån från att dölja det inre. I offentligheten framstår det privata som avgränsat och kringgärdat, och det är det allmännas plikt att bevara de gränser och gärdsgårdar som skiljer 
en medborgares egendom och intimitet från grannens och som skyddar dem mot honom. Det vi idag kallar lagar betydde åtminstone hos grekerna ursprungligen något i stil med gräns.” (Arendt 1988, 88, jmf. 85f.).

Låt mig passera alla statiska distinktioner mellan det offentliga och det privata och istället koncentrera på relationen mellan egendom och lag. ${ }^{28} \mathrm{Med}$ dessa rader tycks Arendt reiterera en traditionell individualistisk förståelse av egendom och integritet - men endast för att genast sammanföra denna med sin motsats: Såsom födelsens och dödens ort var, skriver Arendt med en hänvisning till antiken, hushållets och egendomens sfär också privat i en icke privativ mening. Karaktären av att vara förborgad från offentligheten "svarade mot det enkla faktum att människan inte vet varifrån hon kommer när hon föds eller varthän hon går när hon dör.”(Arendt $1988,88)$ Med denna formulering framträder skillnaden mellan å ena sidan en individualistisk egendomstradition och å andra sidan Arendts syn på egendom med skärpa: Betydelsen av egendom (Eigentum) - ett ord vars etymologi är knutet till självet, till betydelsen att vara sin egen (eigen), att vara unik (eigentümlich); (Liedman 61ff.) - blir i Arendts filosofi själva omöjligheten att appropriera livets början och dess slut. Det som är mig mest eget är samtidigt det mest främmande. Födelse och död sätter gränser för människorna och det är samtidigt dessa gränser som öppnar för ett liv i världen - och som därmed öppnar upp för en unik livshistoria, vilken bryter av en annars dödslös repetition. ${ }^{29}$

Men människorna kan inte sätta sina egna gränser och de kan heller inte i strikt mening äga sig själva, sin början eller sitt slut - det vill säga sin egendomlighet (Eigentümlichkeit). Att vara hemma i världen är för Arendt inte att vara hemma eller ha en fast identitet i en gemenskap eller i sig själv - utan att vara hemma i det specifika självförfrämligande som karaktäriserar ett liv i rum och tid. Och då Arendt skriver in detta förfrämligande i sitt egendomsbegrepp framträder hon som en egendomsteoretiker av säreget slag. Den individualistiska, huvudsakligen liberala definitionen av människan som en suverän och oberoende ägare av sig själv, förbyts till ett perspektiv i vilket vi är villkorade - inte helt tagna i besittning, inte fullständigt obundna. Däri består, eller snarare skapas, vår unicitet eller egendomlighet - de mänskliga verksamheternas fundamentala skörhet, men också deras storhet: För detta självförfrämligande eller denna ogenomskinlighet är för Arendt också förutsättningen för politiskt handlande och tal, och således för frihet och autonomi under den mänskliga pluralitetens villkor.

28 Den dialektik som Arendt presenterar upphävs aldrig i en ny enhet. Var denna gräns skall dras och således vad av egendomens inre som är politiskt är, som också Arendts text indikerar en politisk fråga - liksom själva föreställningarna om vad som är privat, som Arendt själv visar, har förändrats genom historien. Och med historiska förändringar rörande bl.a. de övervakande makternas organisering och informationsteknologiska innovationer blir det en ständigt aktuell uppgift att tänka kring denna gräns.

29 Den mänskliga tillvaron skulle - om det inte existerade en värld som människor föds in i och dör bort ifrån verkligen likna Nietzsches eviga återkomst, skriver Arendt. Och detta vore människosläktets eviga dödslöshet. Det är också denna aspekt av livet som Arendt benämner zoe (Arendt 2004, 49; jmf. Arendt 1988, 124). 
Då man handlar och talar avtäcks enligt Arendt aspekter av vem någon är. Dessa vem är delvis ogenomskinliga för sig själva, men deras mångtydighet och unicitet framskymtar för andra också då det egentliga innehållet för handlande och tal rör ting som angår världen: de objektivt-världsliga intressen som i ordets ursprungliga betydelse är "något som inter est, som ligger mittemellan och upprättar de relationer som förbinder människor med varandra och samtidigt skiljer dem åt.” (Arendt 1988, 220) Den specifika form av självförfrämligande som Arendt skriver in i egendomsbegreppet, finner således sin motsvarighet i hennes förståelse av politiskt handlande: Själva min tillblivelse och unicitet förutsätter de andra - förstått både som den värld och de andra som villkorar mig. Och då varje blottläggande av vem man är liksom av världen är partiellt förblir ett vem alltid något sam existerar i form av en fråga - vem? - och som syftar på en essens i tillblivelse (Arendt 1988, 223, 234). Och detta är, som vi har sett, skälet till att en unik levnadshistoria, enligt Arendt, endast kan återberättas postumt. Från ett arendtskt perspektiv utgörs Fantominas öde av det faktum att hon spelar upp en individualistisk antropologi. Då Fantomina gör sig till suverän författare över sitt liv, blir hon som mest underordnad: hennes unicitet kommer aldrig till uttryck i tal och handlande med andra.

Betydelsen av Arendts omtolkning av egendomsbegreppet - av sammanbringande av radikalt motsatta perspektiv - tycks också flerfaldig i relation till användandet av kroppar i dagens identifieringssystem. Arendt ställer oss inför den filosofiska uppgiften att $\mathrm{i}$ uppgörelsen med individualismen inte aningslöst upplösa subjektet på ett sådant sätt att vi förbiser den fundamentala skörhet som vidhäftar människors kroppsliga villkor, och att vi därigenom förbiser betydelsen av lag som gräns. Men den gräns som Arendt formulerar omgärdar inte oberoende individer i suverän besittning av sig själva - sina kroppar, och sina tankar - bortom tid och rum. Gränsen får sin betydelse i relation till ett delvis ogenomskinligt vem i ständig tillblivelse - i relation till vem, vars unicitet är beroende av den värld och de andra som villkorar dem. Kanske kan vi formulera det som att denna gräns istället för att resa frågan om vad som skall skyddas i sitt oberörda tillstånd reser frågan om hur - och i denna hurfråga ryms också frågan om hur olika tekniker villkorar oss. För att förstå innebörderna av dagens identifieringstekniker, kan vi inte falla åter $i$ en föreställning om ett fritt svävande medvetande - eller i synen på information som ett fluidum utan kropp - och inte heller kan vi stanna vid en förståelse av kroppen som en oberoende enhet. Med frågan om hur blir förvisso inte integritetsfrågan, eller den vidare frågan om kroppsliga fri- och rättigheter, löst på förhand. Tvärtom blir det en ständigt förnyad uppgift att tänka kring denna gräns - och frågan tar en ny vändning då det är min tillblivelse som står på spel: inte i första hand vad jag är eller kan bli, utan själva möjligheten att bli till. 


\section{Glömska, eller: Rättigheter som inter-est}

Det är min tillblivelse som står på spel, vilket förutsätter ett skydd för den externa kontingenta kropp som är min, liksom den vidare hur-fråga som genereras tycks möjliggöra en kritisk reflektion över den samtida användningen av kroppar i identifieringssystem. Kanske kan vi formulera dessa kroppars sårbarhet i relation till en specifik form av glömska: ${ }^{30}$ Nietzsches aktiva glömska vars förmåga att skapa en liten tabula rasa bryter igenom resentiment och hämndbegär för att skapa utrymme för det nya. En glömska - som genom att frisläppa från det förflutna öppnar upp för en ny början, en fortsatt tillblivelse - vilken Arendt översätter till förlåtelse, och tillskriver en politisk betydelse (jmf. Kristeva 213-215, 231f.). För att en avslutande gång återvända till skriftens fälla: Dagens identifieringssystem arbetar genom att abstrahera; i en dubbel rörelse splittrar de upp och isolerar kroppen enligt förutbestämda kriterier och därigenom låser de antingen kroppen vid en förfluten händelse (ett snatteri, en förbjuden flyktväg, en otrohet, våldtäkt eller en misslyckad gränsövergång utan de rätta dokumenten) eller vid en misstanke om en kommande händelse: en händelse som blir oförlåtlig och vars verkningar heller inte upphör med ett fullgjort straff. I denna mening kan vi kanske artikulera dessa kroppars sårbarhet i termer av ett upphävande av deras tidslighet - och i extremfallet: ett utkastande i en dödslös repetition.

Och denna oförmåga att glömma tycks i sin tur kunna förstås som en annan form glömska. Kanske återspeglas denna temporala oförsonlighet i en specifik glömska av rum (och således i en glömska av hur min egendomlighet skapas i och genom den värld och de andra som villkorar mig). ${ }^{31} \mathrm{Med}$ ett individualistiskt begrepp om integritet utesluts själva det inter i vilken en unik livshistoria tar form och således rättigheter som inter-est. ${ }^{32}$ Först med ett klart snitt mellan medvetande och kropp, mellan det praktiska och det teoretiska och med en förståelse av autonomi som suverän besittning och transparents och av information som kroppslös, blir frågan om dessa kroppars integritet en icke-fråga. Men det jag som är mitt, är mig inte helt bekant, min egendomlighet inte helt genomskinlig, min kropp inte en enhet avskild från medvetande eller helt avgränsad från mina omgivningar och andra materiella kroppar. ${ }^{33}$ Därför tycks det omöjligt att besvara frågan om min

30 För en diskussion om dataminne och social glömska, se även Blanchette \& Johnson.

31 Det är inte ointressant i detta sammanhang att Arendt karaktäriserar moderniteten i termer av en ständigt pågående alienationsprocess: men inte i termer av ett självförfrämligande utan av ett världsförfrämligande. Och det är, enligt Arendt, framförallt den enorma expropriering av egendom som inleddes under den nya tiden, koloniseringen och vetenskapernas betraktande av jorden från universums ståndpunkt, som utgör de olika "modi i vilka världen förfrämligas” vilka leder fram till modernitetens radikala världsförfrämligande (Arendt 1988, 297-303, 373). Och denna syn på relationen mellan självet och världen finner sin pendang i hennes omtolkning av mänskliga rättigheter till en rätt att ha rättigheter, vilket är att ha en plats i världen, jmf. resonemanget om Ricoeur i noten nedan.

32 Jmf. Hayles $(1999,288)$ : "the very illusion of control, bespeaks a fundamental ignorance about the nature of the emergent processes through which consciousness, the organism, and the environment are constituted." $(1999,288)$ I denna mening kan vi tala om en glömska av de sätt på vilka vi alltid har varit "posthuman".

33 Jmf. Butler $(2004,26)$ skriver: "Given over from the start to the world of others, it bears their imprint, is for- 
integritet genom en rad aprioriska distinktioner. Snarare är det just själva glömskan av rum - och därmed glömskan av att vi är villkorade, hybridiska - som genererar våra identifierade kroppars sårbarhet.

Och det inter som här står på spel har också en politisk betydelse. Det är, för att återknyta till Arendt, inte något som föreligger i ett eller annat territorium. Detta inter skapas genom handling. Handlandet är för Arendt inte bara en förmåga att skapa något nytt - ett svar på födelsens faktum - utan också, med Adriana Cavareros ord, "a relational event that generates space for reciprocal self-revelation." (Cavareros 2002, 514; Arendt 1988, 242) Med andra ord rör detta inter inte bara sårbarheten hos de kroppar som huserar i dagens identifieringssystem. Själva illusionen om suverän kontroll - ur vilka olika former av säkerhetsparadigm, med förödande konsekvens, hämtar näring - utgör närmast ett bland en mångfald försök att beröva sig själv en politisk förmåga: Ett försök att glömma vår gemensamma förmåga att generera rum, att skapa rum för det oförutsedda, i handlande och tal med andra och således att skapa "nya verkligheter". Illusionen om suverän kontroll, individuell såväl som nationell eller global, utesluter politik; politisk autonomi, likväl som ansvar. Men detta glömda har inte status av en enhet eller en begravd skatt. Det glömda är verksamt, och därmed är det inte ett förflutet som en gång har varit, utan utgörs snarare av kraften i att vara-tilsammans vilken vi, som Ricoeur skriver i en analys av Arendts maktbegrepp, är utan att se (Ricoeur 399) ${ }^{34}$ Den historiska och teoretiska uppgift i vilken denna text tog sin början, är därför samtidigt politisk liksom den genererar en rad frågor om hur att förstå rättigheter.

Låt mig avsluta med frågan om rättigheter som inter-est - inte med mänskliga rättigheter, utan med Arendts ord, med "rätten till rättigheter". "Rätten till rättigheter” rör ett krav på deltagande i politikens mellanrum: ett krav på en plats från vilken åsikter kan skapa mening, och handlingar bli meningsfulla. "Rätten till rättigheter" är, enligt Arendt, en rätt till en plats i världen (Arendt 1979, 296-97). ${ }^{35}$ Och kanske är det först genom ett försök att förstå rättigheter i relation till "världens metamorfos i människan" 36 - i relation till ett vem? i ständig tillblivelse - som

med within the crucible of social life; only later, and with some uncertainty, do I lay claim to my body as my own, if, in fact, I ever do.”

34 Med Ricoeurs ord: Glömskan av vad som konstituerar vårt gemensamma liv tillsammans "does not send us back to some past which might once have been experienced by members of a self-consciously transparent society aware of the manner of its generation, individually and collectively. I must insist upon this point: it is a form of forgetfulness that does not bear upon the past. In this sense, a forgetfulness without nostalgia." Det finns, som Ricoeur skriver, ett antal tänkare som cirklar kring idén om ett glömmande utan relation till ett existerande förflutet. Hit hör inte bara Arendt utan också Levinas likväl som Jean-François Lyotard - men inte minst Heidegger som i Sein und Zeit, §7, skriver att det som är oss närmast, samtidigt är det mest fördolda. "That is why phenomenology can only be a form of hermeneutics, that is to say, an interpretation and not a direct intuition." (Ricoeur396).

35 Jag har i en tidigare artikel försökt diskutera betydelsen av Arendts vem? för en icke-suverän föreställning om rättigheter, vilken inte förbiser olika former av exklusioner från de så kallade universella rättigheterna (Johansen 2007).

36 Som Marcia Sá Cavalcante Schuback skriver i essän "Världens metamorfos i människan” lämnar Nietzsche "den gamla metaforen 'världen som text' bakom sig och visar att varken människan eller världen är ett ting, 
somliga rättigheter kan bli lite mindre omänskliga (eller skall jag skriva lite mindre mänskliga). Kanske är det först om vi ersätter den individualistiska frågan om vad vi skulle vara om vi alla var i en fullständig besittning av oss själva bortom tid och rum, med frågan om hur vi alla är villkorade som somliga rättigheter kan bli lite mindre (o)mänskliga.

\section{LITTERATUR}

Agamben, Giorgio. Homo Sacer: Sovereign Power and Bare Life. Stanford: Stanford University Press, 1998.

Agamben, Giorgio. Profanations. Övers. Jeff Fort. New York: Zone Books, 2007.

Amoore, Louise. "Governing by identity". Playing the identity card. Surveillance, security and identification in global perspective. Red. Colin J. Bennett \& David Lyon, London \& New York: Routledge, 2008.

Anderson, Laurie. "From the Air". Big Science. Warner Bros Records, 1982.

"Anmärkningar mot förslaget till Rättegångsbalk vid 1734 års riksdag", 4. Af Häradshöfding P. Abrahamsson. Förarbetena till Sveriges rikes lag 1686-1736. Efter offentligt uppdrag utgifna af Wilhelm Sjögren, VIII, Riksdagshandlingar angående lagkommissionens förslag. Uppsala, 1909.

Arendt, Hannah. "Historiebegreppet: Det antika och det moderna". Mellan det förflutna och framtiden: Åtta övningar i politiskt tänkande. Övers. Annika Ruth Persson. Göteborg: Daidalos, 2004.

Arendt, Hannah. Människans villkor. Vita activa. Övers. Joachim Retzlaff. Göteborg: Röda Bokförlaget, 1988.

Arendt, Hannah. The Origins of Totalitarianism. New York: Harcourt Brace, 1979 (1951).

Backscheider, Paula R. "Introduction". Selected Fiction and Drama of Eliza Haywood. Red. Backscheider, Paula R. New York, Oxford: Oxford University Press, Serien Women Writers in English 1350-1850, 1999.

Barnombudsmannen. Remissvar. (SOU 2002:13), 2002-07-29, ställt till Utrikesdepartementet. Diarienummer: 4.1:0393/02. 〈http://www.bo.se/Adfinity.aspx?pageid=3440\#>

Barthes, Roland. "From Speech to Writing". The Grain of the Voice. Interviews 1962-1980. Overs. Linda Coverdale. Hill og Wang: New York, 1985.

Bentham, Jeremy. Panopticon: En ny princip för inrättningar där personer övervakas. Övers. Frans Lundgren. Nora: Nya Doxa, 2002.

Blanchette, Jean-François och Johnson, Deborah G. "Data retention and the panoptic society: The social benefits of forgetfulness". The Information Society. 18 (2002:1).

Bogard, William. The Simulation of Surveillance: Hypercontrol in Telematic Societies. Cambridge: Cambridge University Press, 1996.

Bozovic, Miran. "An utterly dark spot”. The Panopticon Writings. Jeremy Bentham. London: Verso, 1995. Butler, Judith. "Giving an account of oneself". diacritics 31 (2001:4).

inget faktum utan en uppgift. Idén om världens text växer ur en strävan att hitta världens urmening eller sanning. Texten blir en värld när det inte längre är meningens sanning utan världens metamorfos i människan som eftersträvas.” (Schuback 81). 
Butler, Judith. Precarious life: The powers of mourning and violence. London: Verso, 2004.

Caplan, Jane. “This or That Particular Person': Protocols of Identification in Nineteenth-Century

Europe”. Documenting Individual Identity. Jane Caplan \& Johan Torpey. Princeton: Princeton University Press, 2001.

Cavarero, Adriana. "Politicizing Theory". Political Theory 30 (2002:4).

Cavarero, Adriana. Relating Narratives. Storytelling and selfhood. New York: Routledge, 2000.

Davies, Natalie Zemon. Martin Guerres àterkomst. Overs. Ingemar E. Nilsson. Stockholm: Ordfront, 1985.

Deleuze, Gilles. "Postskriptum om kontrollsamhällena”. Overs Bo Isenberg, Res Publica. Nr. 23 (1993).

Doniger, Wendy. The Bedtrick: tales of sex and masquerade. Chicago: University of Chicago Press, 2000.

Ernst, Wolfgang. Sorlet frän arkiven. Ordning ur oordning. Overs. Tommy Andersson. Göteborg: Glänta produktion, Mediehistoriskt bibliotek nr. 4, 2008.

Europarådets rekommendation No. R (92) 1.

Foucault, Michel. "Lives of infamous men". Essential works of Foucault, 1954-1984. Vol 3 Power. Red. James D. Faubion. New York: The New Press, 2000.

Foucault, Michel. "Politics and Reason". Politics, Philosophy, Culture. Interviews and Other Writings 1977-1984. Red. Lawrence D. Kritzman. New York: Routledge, 1990.

Foucault, Michel. Övervakning och straff: Fängelsets födelse Overs. C. G. Bjurström. Lund: Arkiv, 1987.

"Genomförande av EG-direktivet om rätt till familjeåterförening samt vissa frågor om handläggning och DNA-analys vid familjeåterförening”. Prop. 2005/06:72. Stockholm 20060202 (Göran Persson och Barbro Holmberg, Utrikesdepartementet).

Galloway, Alexander R. \& Thacker, Eugene. The Exploit. A Theory of Networks. Minneapolis: University of Minnesota Press, 2007.

Groebner, Valentin. "Describing the Person, Reading the Signs in Late Medieval and Renaissance Europe: Identity Papers, Vested Figures, and the Limits of Identification, 1400-1600”. Documenting Individual Identity. Red. Jane Caplan \& John Torpey. Princeton: Princeton University Press, 2001.

Groebner, Valentin. Personbevis. Passets födelse i medeltidens Europa. Overs. Tommy Andersson. Göteborg: Glänta produktion, skriftserien Mediehistoriskt bibliotek 5, 2009.

Haggerty, Kevin D. \& Ericson, Richard V. “The New Politics of Surveillance and Visibility”. The New Politics of Surveillance and Visibility. Red. Kevin D. Haggerty \& Richard V. Ericson. Toronto: University of Toronto Press, 2006.

Haggerty, Kevin D. och Ericson, Richard V. "The surveillant assemblage”. British Journal of Sociology. 51 (2000:4).

Hayles, N. Katherine. "Flesh and Metal: Reconfiguring the Mindbody in Virtual Environments". Configurations 10 (2002).

Hayles, N. Katherine. How we became posthuman. Chicago: Univ. of Chicago Press, 1999.

Haywood, Eliza. "Fantomina: or, Love in a Maze". Secret Histories, Novels, and Poems, by Eliza Haywood. (2. udg.) London: Dan Browne og S. Chapman, 1725. III, 2.

Hobbes, Thomas. Leviathan. Cambridge: Cambridge University Press (Cambridge texts in the history of political thought), 1991.

Inger, Göran. Vanfrejd. Frän infamia till förlust av medborgerligt förtroende. Uppsala, 2001.

Johansen, Maria. "De mänskliga rättigheternas paradox". Glänta nr. 1(2007). 
Johansen, Maria. Offentlig skrift om det hemliga. Raison d'État, SOU och varulven. Göteborg: Glänta, 2005. Kittler, Friedrich. Maskinskrifter: essäer om medier och litteratur. Red. Otto Fischer \& Thomas Götselius. Övers. Tommy Andersson. Gråbo: Anthropos, skriftserien Mediehistoriskt bibliotek, 2003.

Kristeva, Julia. Hannah Arendt. Övers. Ross Guberman. New York: Columbia University Press. 2001.

Liedman, Sven-Eric. Tankens lätthet, tingens tyngd. Om fribet. Stockholm: Bonniers, 2004.

Locke, John. "The Second Treatise of Government". Two Treatises of Government. Cambridge: Cambridge University Press, 1988.

Lyon, David. "Surveillance as Social Sorting. Computer Codes and Mobile Bodies". Surveillance as Social Sorting. Red. David Lyon. London: Routledge, 2003.

Masters, Christina. "Bodies of Technology. Cyborg soldiers and militarized masculinity". International Feminist Journal of Politics. 7:1 (2005).

Mill, John Stuart. Om fribeten. Övers. Alf Ahlberg. Stockholm: Natur och kultur, 1995.

"Motiver". Förslag till Allmän Criminallag (1832. Andra upplagan, med de förändringar hwilka Lagcommitten wid slutlig granskning af förslaget infört). Stockholm, 1839.

van der Ploeg, Irma. "Biometrics and the Body as Information. Normative Issues of the Sociotechnical Coding of the Body". Surveillance as Social Sorting. Red. David Lyon. London: Routledge, 2003.

van der Ploeg, Irma. "The Illegal Body: 'Eurodac' and the Politics of Biometric Identification”. Ethics and Information Technology 1 (1999).

Richert, Johan Gabriel. "Försök: Om strafflagarna”. Rättshistoriska studier. Skrifter utgivna av institutet för rättshistorisk forskning (serie II, band 5). Stockholm: Nerenius \& Santérus, 1977.

Ricoeur, Paul. "Power and violence". Hannah Arendt: Critical Assessments of Leading Political Pbilosophers. Red. Garrath Williams. London \& New York: Routledge, 2006.

Riksdagens protokoll 2005/06:97, §7. 〈http://www.riksdagen.se/Webbnav/index. aspx?nid=101\&bet $=2005 / 06: 97>$.

Ruin, Hans. "Vetande och öde - om genetikens etiska fordran". Genetikens möjligheter och problem. Red. Tommy Möller, Stockholm: Pensionsforum, 2004.

Schmitt, Carl. "Definition av suveräniteten”. Övers. Ingemar Johansson. Res Publica, nr. 23 (1993): 86-95.

Schuback, Marcia Sá Cavalcante. "Världens metamorfos i människan: Anteckningar kring Nietzsches syn på text och tolkning". Om text. En vänbok till Eva-Lena Dabl. Red. Maria Johansen \& Thomas Karlsohn. Göteborg: Göteborgs Universitet, Arachne nr. 18, 2002.

Shapiro, Michael. Gender in Play on the Shakespearean stage: Boy Heroines and Femal Pages. Ann Arbor: The University of Michigan Press, 1996.

"Skyddet för den personliga integriteten. Kartläggning och analys. Delbetänkande av integritetsskyddskommittén". SOU 2007:22. del I.

Solove, Daniel J... The Digital Person: Technology and Privacy in the Information Age. New York \& London: New York University Press, Serien Ex Machina: Law, Technology, and Society, 2004.

Socialförsäkringsutskottets betänkande 2005/06:SfU8. <http://eu-upplysningen.se/webbnav/index. aspx?nid=3322\&dok_id=GT01SfU $8 \& \mathrm{rm}=2005 / 06 \&$ bet $=$ SfU $8>$.

"Säkerhetspolisens arbetsmetoder. Rapport av särskild utedare". SOU 1989:18. Stockholm: Civildepartementet. 
"SÄPO. Säkerhetspolisens arbetsmetoder, personalkontroll och meddelarfrihet. Slutbetänkande av SÄPO-kommittén”. SOU 1990:51. Stockholm: Civildepartementet.

Thacker, Eugene. "Data Made Flesh: Biotechnology and the Discourse of the Posthuman". Cultural Critique 53 (2003).

"Utlåtande, i anledning af Anmärkningar wid Förslaget till Allmän Criminallag” (1834). Förslag till Allmän Criminallag (1832). Stockholm, 1839.

"Utredning och förslag om borttagande ur lagstiftningen av straffpåföljden förlust av medborgerligt förtroende". Bihang till riksdagens protokoll vid lagtima riksdagen i Stockholm år 1917. (Andra samlingen. Andra Avdelningen. Andra Bandet: 1, MOTIV) Stockholm.

"Utvidgad användning av DNA-tekniken inom brottsbekämpningen m.m”. Prop. 2005/06:29. Stockholm 20051013. (Göran Persson och Thomas Bodström. Justitiedepartementet).

Österberg, Eva. "Heder, hat och förtvivlan”. Hedersmord. Tusen år av hederskulturer. Red. Kenneth Johansson. Lund: Historiska Media, 2005. 